\title{
State of Information and Communication Technology (ICT) Usage in the Training of Construction Students in Ghanaian Technical Universities
}

\author{
Simon Ofori Ametepey ${ }^{1 *}$, William Gyadu-Asiedu², and Samuel K. Ansah ${ }^{3}$ \\ ${ }^{102}$ Faculty of Built and Natural Environment, Koforidua Technical University, Koforidua - Ghana \\ ${ }^{3}$ Building Technology Department, Cape Coast Technical University, Cape Coast_Ghana
}

${ }^{1}$ Correpondence: simon.ametepey@,k.tu.edu.gh

\begin{abstract}
In recent years, the construction sector has undergone impressive developments in the use of ICT. Thus, placing much demands on capacity building that will produce an adequate, highly skilled workforce to manage the growing technology in the industry. ICT takes the front role and essentially becomes the medium in which all the other operations are carried out. Most researchers, thinkers and educators have taken up the challenge of using ICT since the 1980s with varied successes. For this reason, this paper assesses the extent to which ICT is used in the training of construction students in technical universities in Ghana. Quantitative method (questionnaire) was employed to elicit data from construction lecturers and students in five technical universities in Ghana. Descriptive statistics and factor analysis were adopted in analyzing the data. The research discovered that ICT adoption in training construction students in Ghanaian technical universities is very low. The study also established twenty-four (24) factors as constraints to ICT usage in construction students' training in technical universities in Ghana. These come under "technology constraints", "economic constraints", "human constraints", "environmental constraints," and "administrative constraints". There is, therefore, a pressing need for a drastic shift towards integrating Construction related ICT tools in training construction students in Ghanaian technical universities.
\end{abstract}

Keywords: Construction Education; Ghana; Information and Communication Technology; Technical Universities; Tertiary Institutions

Citation: Ametepey, S. O., Gyadu-Asiedu, W. and Ansah, S. K. State of Information and Communication Technology (ICT) Usage in the Training of Construction Students in Ghanaian Technical Universities, 2020; 5(3): 86-95.

Received: May 20, 2020

Accepted: September 30, 2020 


\subsection{Introduction}

Education generally determines the level of advancement of a nation, society and the individual. Appropriate Education makes way for appropriate technological development (Desai, 2010). According to the World Bank (1998), tertiary education must be the vanguard for this transformation, and Information Communication Technology (ICT) must be promoted as a primary training facility. Danso (2012) also reiterated that tertiary institutions must encourage highly appropriate courses that represent the skills needed in today's working world.

Polytechnics in Ghana were converted to Technical Universities in 2016. They have a significant role in the country's required skilled labor (Aidoo-Tailor, 2009; Owusu-Agyeman \& Osterkamp, 2009). For this reason, all technical universities must ensure that they adequately train their graduates to meet the demands of the job market. With ICT appearing in all areas of development, including the construction industry, construction education in technical universities cannot underestimate ICT in their training. The Skills Development Fund (2011) affirmed that Ghana's developmental success must be powered by skills, knowledge and innovation in the construction sector. This vision can be accomplished where construction educational institutions are committed to training characterized by the capacity to innovate, compete and thrive to ensure the socio-economic development of the nation. Increasingly, society advocates for technology-savvy workers to enhance creativity and efficiency (Nwosu \& Ogbomo, 2011). This can be achieved by ascertaining dependable information sources and finding the best means of accessing this information for use (Nwosu \& Ogbomo, 2011).

In recent years, the construction sector has experienced impressive developments in the use of ICT. (Loosemore et al., 2003). Therefore, Construction training should concentrate on creating sustainable information and professional workforce in Technology adoption to enhance efficiency and productivity within the construction industry. Most workers worldwide have taken up the challenge of using ICT since the 1980s with varied successes.

Ghana's construction sector must follow the actions of the developed countries by integrating ICT into construction activities. The adoption of ICT in the construction sector in Ghana will help to strengthen the existing limitations of the sector (Fugar, Ashiboe-Mensah, \& Adinyira, 2013). Therefore, the education sector, particularly technical universities providing construction education, have a role to play.

Construction education is essential for nation-building in industrialized and emerging economies. The quality of construction professionals affects the delivery of construction projects. It is, therefore, critical to build the capacity of the construction workforce for efficient and effective project delivery and to also ensure the success of the sector. The construction sector in Ghana is low in technology adoption and more manual driven as compared to other sectors (Fugar, Ashiboe-Mensah, and Adinyira, 2013). Therefore, the continuous delivery of the obligation of the construction industry depends on its human capital development (Ofori, 2012).

Evidence abounds on the usage of computers and ICT in Construction estimating, construction planning, surveying, procurement, electronic tendering and robotics in construction intelligence building elsewhere in the world (Harris \& McCaffer, 2001). Despite the forgoing, not much is encountered in the literature regarding empirically documented works on the state of ICT on construction education in Ghana. It is against this backdrop that this research sought to evaluate the state of ICT usage in training construction students in Technical Universities in Ghana.

\subsection{ICT in construction education}

ICTs in construction training require the implementation of general ICT elements in the process of teaching and learning. Globalization and international transformation have created a modern, technologically based, 
information-driven, knowledge-driven global economy. This current world economy has major consequences for the existence and function of academic institutions. ICT has transformed conventional construction approaches and doings, offering new dimensions for teachers, learners, and researchers. Prospective Technical University graduates ought to be compliant with the ever-expanding knowledge and trained with the requisite technologies.

The involvement of ICT in teaching and learning plays a critical role, particularly in empowering technology in learning programs (Kaka, 2008). ICT is considered the center of education due to its presence in mainstream and unique settings and numerous educational establishments. Numerous scholars contend that this era requires selfconfidence and efficiency in the use of ICT in all disciplines, both at industry and academia levels, to make learners productive. However, there is several roles ICT play in equipping students to function well in their world of work. ICT strives to foster a culture of diversity and cooperation, building on individual talent and unique capacities, introducing 'new worlds' to instructors exploring innovative avenues to support learners move beyond the classroom, school, and society. In Africa, evolving electronic messaging offers more guidance and opportunities for different styles and levels of cooperation between different institutions (Nwoso \& Ogbomo, 2011). ICTs create interactive learning and power-sharing and influence that encourages students to study according to their cultural style. In construction education in the West, Students are responsible for researching and being open-minded about these new ICT dealings. The technology revolution gives Africa a remarkable opportunity to leapfrog into the future from centuries of sluggish growth. Therefore, to prevent marginalization, African academics and universities must seize the opportunity to implement communication technologies.

\subsection{Methodology}

The quantitative research design (questionnaire survey) was adopted for the study. The research population consisted of final-year students pursuing Building Technology and Civil Engineering programs and lecturers conducting these programs at the eight technical universities in Ghana. A multi-stage sampling method was employed to select the participants. First, a simple random sampling method was applied to choose five (5) out of eight (8) technical universities. Where a university runs a single construction-related program, it was selected automatically for the survey. In schools with more than one construction-related program, one program was deliberately chosen to ensure equal representation. All selected program's final year students and their lecturers were part of the study sample. The survey selected 275 final-year students and 50 lecturers.

The questionnaire utilized in this study was closed-ended and was in three sections. Part I sought to investigate the characteristics of the respondents. The second part evaluated the use of ICT software in training construction students in technical universities. The final part investigated the Constraints on ICT usage in training construction students in technical universities. The questionnaire was structured in a Likert scale form for most of the sections.

Statistical Package for Social Sciences (SPSS) was the primary tool adopted for the data analysis. The main statistical methods of analysis adopted were percentages, tables, averages and frequencies in summarizing respondent details. Factor analysis was utilized to evaluate the inherent interdependencies between the several constructs defined as the barriers to ICT software usage in technical university training. The factor analysis method helps in reducing the variables to a more functional setting. Table 2 shows the rotated component matrix. The Kaiser-Meyer - Olkin (KMO) sampling adequacy test reached 0.925 in the preliminary study. All 24 variables had 1.00 communalities or higher, suggesting their suitability for factor analysis. The 24 constructs were condensed to standard factor patterns. These were undertaken to scientifically illustrate the challenges of using ICT software in Technical Universities educating construction students. In doing this, principal component analysis with Varimax rotation and Kaizer Normalisation was used to determine which factors have empirical significance. Factor retention was by the eigenvalue 1.0 criterion, suggesting that only factors that account for variances greater than 
one should be included in the factor extraction. The principal component analysis, where linear combinations of observed variables are developed was the technique for extracting the variables.

\subsection{Results and Discussions}

\subsection{Background of respondents}

Concerning faculty of affiliation, it was realized that the majority $(66 \%)$ of the respondents were affiliated to the school of engineering. In contrast, the remaining respondents (34\%) were affiliated to the faculty of built and natural environment. In terms of departmental affiliation, $38 \%$ of the respondents were affiliated to the civil engineering department, while $62 \%$ of the respondents were affiliated to the building technology department. Furthermore, the majority $(93 \%)$ of the respondents were males, while the remaining $(7 \%)$ were females. This finding can be attributable to the reality that Construction is a male-dominated field.

\subsection{Usage of ICT tools in training construction students}

The survey examined the lecturers' and students' usage of ICT tools in training construction students in technical universities in Ghana.

Table 1: Usage of ICT Tools in Construction Students Training

\begin{tabular}{|c|c|c|c|c|c|c|}
\hline \multirow{2}{*}{ Usage of ICT tools } & \multicolumn{2}{|c|}{ Lecturers } & \multicolumn{2}{|c|}{ Students } & \multicolumn{2}{|c|}{ Overall } \\
\hline & Mean & Rank & Mean & Rank & Mean & Rank \\
\hline \multicolumn{7}{|l|}{ Word processing } \\
\hline 1. $\quad$ Microsoft Word & 4.30 & 1 & 3.90 & 1 & 4.10 & 1 \\
\hline 2. $\quad$ Word Perfect & 1.80 & 10 & 1.30 & 12 & 1.60 & 11 \\
\hline \multicolumn{7}{|l|}{ Presentation } \\
\hline 3. $\quad$ Adobe PageMaker & 1.40 & 14 & 1.20 & 16 & 1.30 & 15 \\
\hline MS PowerPoint & 3.20 & 4 & 2.40 & 5 & 2.80 & 4 \\
\hline MS Outlook & 1.50 & 13 & 1.40 & 11 & 1.50 & 13 \\
\hline \multicolumn{7}{|c|}{ Architectural Design and Drawing } \\
\hline $\begin{array}{ll}6 . & \text { CorelDraw } \\
\end{array}$ & 2.20 & 9 & 1.80 & 9 & 2.00 & 9 \\
\hline 7. $\quad$ AutoCAD & 2.80 & 5 & 2.30 & 6 & 2.60 & 6 \\
\hline ArchiCAD & 2.60 & 8 & 2.10 & 8 & 2.40 & 8 \\
\hline 9. $\quad$ Chief Architect & 2.80 & 5 & 2.50 & 4 & 2.70 & 5 \\
\hline \multicolumn{7}{|l|}{ Project Planning } \\
\hline 10. MS Project & 2.80 & 5 & 2.20 & 7 & 2.50 & 7 \\
\hline 11. Prima vera & 1.20 & 19 & 1.10 & 20 & 1.20 & 19 \\
\hline \multicolumn{7}{|l|}{ Structural Design } \\
\hline 12. APM Civil Eng. & 1.10 & 23 & 1.00 & 24 & 1.10 & 23 \\
\hline 13. Monomakh & 1.30 & 17 & 1.10 & 20 & 1.20 & 19 \\
\hline 14. Robot & 1.30 & 17 & 1.20 & 16 & 1.30 & 15 \\
\hline 15. Lira & 1.20 & 19 & 1.10 & 20 & 1.20 & 19 \\
\hline 16. SCAD & 1.40 & 14 & 1.30 & 12 & 1.40 & 14 \\
\hline \multicolumn{7}{|l|}{$\begin{array}{l}\text { Quantity Surveying Measurement } \\
\text { Estimating }\end{array}$} \\
\hline 17. WinOS & 1.20 & 19 & 1.30 & 12 & 1.30 & 15 \\
\hline 18. CatoPro & 1.20 & 19 & 1.20 & 16 & 1.20 & 19 \\
\hline 19. MasterBill & 1.80 & 10 & 1.60 & 10 & 1.70 & 10 \\
\hline
\end{tabular}




\begin{tabular}{|l|l|l|l|l|l|l|} 
20. QS Elite & 1.40 & 14 & 1.20 & 16 & 1.30 & 15 \\
\hline 21. SnapeVector & 1.10 & 23 & 1.10 & 20 & 1.10 & 23 \\
\hline 22. Revit & 1.80 & 10 & 1.30 & 12 & 1.60 & 11 \\
\hline Communication & & & & & & \\
\hline 23. E-mail & 4.10 & 2 & 3.40 & 3 & 3.80 & 2 \\
\hline $24 . \quad$ Internet & 3.80 & 3 & 3.80 & 2 & 3.80 & 2 \\
\hline Overall & $\mathbf{2 . 0 5}$ & & $\mathbf{1 . 7 8}$ & & $\mathbf{1 . 9 5}$ & \\
\hline
\end{tabular}

According to table1, the extent of use of Microsoft word by lecturers recorded a mean of 4.30, whereas students recorded a mean of 3.90, which all represented "regularly". Both participants rated it as the most-used ICT software. For Word perfect, the extent of usage by lecturers recorded a mean of 1.80 while that of students scored 1.30, which implies "very rarely" and "not at all" respectively. Education usually is information-intensive, with a vast amount of knowledge produced and used by all involved. Learners utilize Microsoft word primarily for their tasks and other academic programs. Most lecturers often use Microsoft word to take notes and process their research work. This result is anticipated as software like "Microsoft Office suite" is the most commonly known commercially existing combined software for general works like word processing (Doherty, 1997). According to Goh (2005), the typical types of Construction education software comprise "Microsoft word".

Both participants were requested to show their extent of usage of presentation software. In this regard, the students' degree of usage of "Adobe PageMaker" recorded a mean of 1.20, while the results of the lecturers recorded a mean of 1.40, both implying 'not at all.' With "MS PowerPoint", a mean score of 3.20 was recorded for lecturers and 2.40 for students, which implies "rarely" and "rarely". This result points to the fact that both students and lecturers hardly use these tools for presentation. This result differs from that of Doherty (1997) and Arif and Karam (2001), where they stated that "MS PowerPoint" has gained Much popularity in education due to multiple presentations that are done by both students and lecturers. This difference may be explained by the fact that education has reached a higher stage of development in their part of the world where the research was carried out than in Ghana

In the case of the use of Architectural Design and Drawing tools like the AutoCAD, the responses of the lecturers recorded a mean of 2.80. In contrast, the responses of the students scored 2.30, meaning "rarely" and "very rarely," respectively. In terms of ArchiCAD, a mean value of 2.60 was recorded for lecturers and 2.10 for students, which implies "rarely" and "very rarely". This signified that both lecturers and students do not use these ICT tools regularly in construction education. Howard (1998) Asserted that Computer-Aided Design (CAD) software is commonly used among construction practitioners, with AutoCAD holding the CAD market's most significant share. Therefore it is imperative for Technical Universities to appropriately integrate these tools into its curriculum in training construction professionals. These CAD systems have replaced conventional drawing boards. CAD Software has vastly enhanced drawing. 3D modeling helps designers to explore the internal spatial structure and its interaction with the external world (Ozumba \& Shakantu, 2008).

Concerning the usage of Project Planning software, participants were asked to show their extent of usage. With MS Project, responses from lecturers recorded an average of 2.80, meaning "rarely" used. Conversely, responses from students obtained an average of 2.20, which connotes 'very rarely' used. Concerning Primavera usage, the lecturers' response produced an average of 1.20 and those of the learners obtained an average of 1.10, which both implied "not at all" used. These are all emerging ICT tools that have been introduced to resolve a lot of challenges inherent in the industry. However, these tools are not introduced to construction students in their Education in Technical Universities in Ghana. According to Colwell (2008), Project planning based software is applied in areas such as management of portfolio, scheduling and planning, inventory management, estimating and controlling costs, 
project management and risk management. Management of portfolio helps organizations define, assess, pick and execute the appropriate projects. Scheduling and planning determine project tasks, their relationships, resource commitment needed and duration of project activities. Moniem (2000) opined that cash flow forecasts could be prepared by the input of cost figures. The implications are that there is the need for all Construction related curriculums in technical universities to be reviewed for these aspects of the trade to be included for an all-round training for the students. The lecturers could also be given in-service training in these areas.

Study participants were also required to identify their extent of use of Structural Design software. Regarding APM Civil Engineering usage, the usage level of the students recorded an average of 1.00. At the same time, those of the lecturers obtained an average of 1.10, which all meant "not at all" used. Concerning structural engineering software like Lira, Robot, SCAD and Monomakh, the trainers and learners' response averages were both ranging from 0 to 1.49. This finding implies that all structural engineering software was "not at all" employed by study participants. With structural design components in the syllabus of construction-related programs in Ghanaian technical universities, it is necessary to introduce these tools to both lecturers and students. This will, in the long run, train future construction practitioners for the job market and expose them to emerging industry technologies.

Furthermore, both groups of participants were required to state their extent of usage of quantity surveying/measurement/estimation tools. The extent of usage of MasterBill by lecturers recorded a mean of 1.80, whereas that of learners recorded a mean of 1.60, which both implied "very rarely" used. In terms of Revit, the level of usage of lecturers recorded a mean of 1.80, while students' responses recorded a mean of 1.30 , which represented "very rarely" and "not at all" in that order. The result signifies that these tools are 'not at all' used by the respondents. Cost control is among the construction project's most critical criteria for project success (Oladapo, 2006). Oladapo (2008) established that these tools help project managers generate the budget of projects and track project expenditure (Oladapo, 2006). Several of this software also assists in quantity taking-off and BOQ development. Therefore it is imperative to introduce construction students to these tools so that they will be capable of performing when they get to the job market.

Finally, on communication tools, both study participants were requested to show their extent of e-mail and internet usage. With e-mail usage, the degree of usage of the lecturers achieved an average value of 4.10, which represented "regularly" used. At the same time, those of the learners obtained an average value of 3.40, which implied "rarely" utilized. The learners and teachers ranked this as the second and third most-used ICT software in construction-related education in that order. For internet usage, a mean value of 3.80 was recorded for lecturers and learners, meaning it is used "regularly". The learners and teachers also ranked this in the third and second positions correspondingly. Teachers and students embraced the internet as it could be used as a useful communication tool. Tam (1999) argued that the internet's contribution to educating construction students comes primarily from its ability to quickly link globally to large volumes of information that otherwise would have taken enormous resources.

Overall, the level of usage of ICT resources by lecturers scored an average of 2.05, suggesting "very rarely" usage. At the same time, those of students reported an average of 1.75 , which also implied "very rarely" utilized. Thus, there is ample evidence that the extent of usage of ICT resources in Ghanaian technical university training of construction students is really low.

Constraints to ICT usage in training construction students

The rotated factor matrix, as illustrated in table 2, suggested that the 24 factors may be the inherent patterns of five key components (using a 0.50 cut-off point). For component 1, unguaranteed protection emerged higher with a factor loading of 0.805 , followed by hardware challenges (0.797), rapid technology change (0.767), software challenges (0.742), professional software shortage (0.738), Integration/Compatibility Issues (0.686) and 
respectively. With regards to the second component, Expensive hardware/software cost appeared highest with a loading of 0.819 , accompanied by complexity in showing that the value of ICT is greater than the related expense (0.788), high cost of employing ICT workers (0.635) and lack of funding availability (0.616). Concerning the third component, lack of knowledge/consciousness of available ICT resources came higher with 0.890 loadings, accompanied by Fear/lack of trust of Technology (0.830), Insufficient Training (0.800), Poor Collaboration (0.765), Poor Management (0.687) and Poor Leadership (0.686). Component four had slowly changing Traditional academic managers with 0.820 factor loading, preceded by inadequate/irregular power source (0.784, short-term outlook-driven industry (0.668) and insufficient ICT content in construction training (0.645). Concerning the final component, the lack of management's willingness to value ICT appeared higher with 0.805 factor loading, accompanied by the failure of Managers to liaise with companies on the industry competence requirement $(0.742)$ and concern of ICT rendering professionals unwilling to work (0.654).

The initial eigenvalues indicated that, if all the factors are ranked, the first component had a total variance of 8.202, reflecting 49.047 percent of the complete variance explained of 24 variables. The second component has a total variance of 2.458 , representing 6.232 percent of the 24 -factor total variance. Component three had a variance of 2.044 , representing 4.836 percent of the 24 -factor total variance. The fourth component also had a total variance of 1.433 , representing 4.524 percent of the variance explained. The final component (five) had a total variance of 1.094, indicating 3.277 percent of the 24 -factor total variance. These five components represented $67.919 \%$ of the 24 variables' cumulative variance. Out of the 24 variables selected from literature as constraints to the adoption of ICT tools in training construction students, and verified via questionnaire survey, factor analysis allowed to place 24 constraints under five components. Because most variables in the first component are directly or indirectly related to technological challenges, this component has been labeled as technology constraints. Likewise, considering that almost all the variables in the second component were related to economic challenges, this was classified as economic constraints. The remaining components were labeled as Human Constraints for the third component, Environmental Constraints for the fourth Component and Administrative constraints for the final Component.

Table 2: Rotated Component Matrix

\begin{tabular}{|c|l|c|c|c|c|c|}
\hline & \multicolumn{1}{|c|}{ Constraints } & \multicolumn{5}{c|}{ Components } \\
\hline No. & \multicolumn{1}{|c|}{$\mathbf{1}$} & $\mathbf{2}$ & $\mathbf{3}$ & $\mathbf{4}$ & $\mathbf{5}$ \\
\hline 1 & Rapid technological change & 0.767 & & & & \\
\hline 2 & Hardware Challenges & 0.797 & & & & \\
\hline 3 & Expensive hardware/ software cost & & 0.819 & & & \\
\hline 4 & Poor leadership & & & 0.686 & & \\
\hline 5 & Slowly changing Traditional academic managers & & & & 0.820 & \\
\hline 6 & $\begin{array}{l}\text { Failure of Managers to liaise with companies on } \\
\text { the industry competence requirement }\end{array}$ & & & & & \multirow{2}{*}{0.742} \\
\hline 7 & Insufficient ICT content in construction training & & & & 0.645 & \\
\hline 8 & Poor collaboration & & & 0.765 & & \\
\hline 9 & Lack of funding availability & & 0.616 & & & \\
\hline 10 & Lack of management's willingness to value ICT & & & & & 0.805 \\
\hline 11 & Trustworthiness/ Breakdown Challenges & 0.683 & & & & \\
\hline 12 & $\begin{array}{l}\text { Complexity in showing that the value of ICT is } \\
\text { greater than the related expense }\end{array}$ & & & & & \\
\hline 13 & Integration/ Compatibility Issues & 0.686 & & & & \\
\hline
\end{tabular}




\begin{tabular}{|c|l|l|l|l|l|l|}
\hline 14 & $\begin{array}{l}\text { Lack of knowledge/consciousness of available } \\
\text { ICT resources }\end{array}$ & & & 0.889 & & \\
\hline 15 & Short-term outlook-driven industry & & & & 0.668 & \\
\hline 16 & $\begin{array}{l}\text { The concern of ICT rendering professionals } \\
\text { unwilling to work }\end{array}$ & & & & & 0.654 \\
\hline 17 & Insufficient training & & & 0.800 & & \\
\hline 18 & Professional software shortage & & & 0.687 & & \\
\hline 19 & Poor management & & & & 0.784 & \\
\hline 20 & Inadequate/irregular power source & & & 0.830 & & \\
\hline 21 & Fear /lack of trust in technology & & 0.634 & & & \\
\hline 22 & The high cost of employing ICT Workers & 0.742 & & & & \\
\hline 23 & Software Challenges & 0.805 & & & & \\
\hline 24 & Unguaranteed protection & & & & \\
\hline
\end{tabular}

Extraction Method: Principal Component Analysis

Rotation Method: Varimax with Kaiser Normalisation

The results suggest deficits in terms of ICT contents in training construction students in Technical Universities in Ghana. These shortfalls are due in part to the many facilities and logistical challenges facing Technical University education in Ghana (Owusu-Agyeman \& Oosterkamp, 2009). To address these shortfalls, the following suggestions are proposed:-

- Establishing a reliable source of funding purposely for integrating ICT in Construction related programs

- Introducing ICT in construction education curriculum based on the knowledge and skills required of the construction industry

- Purchasing excellent Construction related software for lecturers to enhance construction student's knowledge and skill acquisition in ICT

- Building capacity of lecturers in the use of Construction related ICT tools

- Instructional methods should include using media technology to improve teaching and learning, including the use of audio and visual technology during teaching.

- Promoting research on issues relating to ICT usage in construction education.

- Review of the curriculum to ICT application in all the functional areas of Construction.

\subsection{Conclusion}

This study offers findings and insights on the usage of ICT in training construction students in Ghanaian Technical Universities. The results offer a synopsis of the scope of ICT usage and limitations on ICT adoption in training construction students in Technical Universities in Ghana. It revealed that the extent of usage of ICT resources in training construction students in Ghanaian technical universities is really low. The limitations of using ICT in construction education relate to technology, economic, human, environment, and administration challenges. The implication is that there is a pressing need for a drastic shift towards integrating Construction related ICT resources in training construction students in Ghanaian Technical Universities. 


\section{Reference}

Ahiaga-Dagbui, D.D., Fugar, F.D.K, McCarter, W.J. and Adinyira, E. (2011). 'Potential risks to international joint ventures in developing economies: the Ghanaian construction industry, In Uwakweh B.O. (Ed.) Procs of the CIBW 107 Conference 1-3 November, 2011 Hanoi -Vietnam, pp. 191-195.

Aidoo-Tailor, N. (2009). Developing advanced technical and vocational skills through Polytechnic education: historical perspective, In G.W. Kouwenhoven, G.K.T. Oduro, and K. Nsiah-Gyabaah, (Eds), Trends in Polytechnic Education in Ghana, (Amsterdam, VU University, 2009).

Arif, A. A. and Karam, A. A. (2001). Architectural Practices and their use of IT in the Western Cape Province, South Africa. Itcon, 6, 17-33. At http://itcon.org/2001/2/

Colwell, D. (2008). Improving Risk Management and Productivity in Megaprojects through ICT Investment. Executive Director Construction Technology Center Atlantic

Danso, H. (2012). Assessment of the awareness of structural computer aided design programs of universities in Ghana. European Journal of Social Sciences, 30(1), 41-47.

Desai, S. (2010). Caste and Census: A Forward Looking Strategy. Economic and Political Weekly, 45(9):1013.

Doherty J. M. (1997). "A Survey of Computer Use in the New Zealand Building and Construction Industry". Journal of Information Technology in Construction - ITCon Vol 2.

Fugar, F.D.K., Ashiboe-Mensah, N.A. and Adinyira, E. (2013). Human Capital Theory: Implications for the Ghanaian Construction Industry Development. Centre of Construction Management and Leadership Development. Journal of Construction Project Management and Innovation Vol. 3 (1): 464-479, ISSN 2223-7852.

Goh B. (2005). IT barometer 2003: Survey of the Singapore construction industry and a comparison of results. Journal of Information Technology in Construction (ITcon), Vol. 10, No. 1, 1-13.

Harris, F. and MacCaffer, R. (2001). "Modern Construction Management.” London: Blackwell Science -5th edition.

Hore, A.V. (2006). Use of it in managing information and data on construction projects - a perspective for the irish construction industry. Information Technology in Construction Project Manageement Engineers Ireland Project Management Society Talk: 21st March 2006

Kaka, S. (2008). The Role of ICT in Education Sector. Inside magazine vol. 02 july 2008

Loosemore, M., Dainty, A. and Lingard, H. (2003). Human resource management in construction projects: strategic and operational approaches. London: Spon Press.

Moniem, A. H. A. (2000). The Role of Project Control Systems in the Integration of the Construction Site Processes. A Case Study Approach, MSc, Loughborough University

Nwosu, O. \& Ogbomo, E. F. (2011). ICT in Education: a catalyst for effective use of information. Delta State University, Abraka.

Ofori, G. (2012). Developing the Construction Industry in Ghana: the case for a central agency.

Oladapo, A. A. (2006). The impact of ICT on professional practice in the Nigerian construction industry, The Electronic Journal of Information Systems in Developing Countries, 24(2), 1-19.

Owusu-Agyeman, Y. and Oosterkamp, M.V.D. (2009). Challenges facing Polytechnic education in Ghana, in Trends in Polytechnic Education in Ghana, In G.W. Kouwenhoven, G.K.T. Oduro, and K. NsiahGyabaah, (Eds), (Amsterdam, VU University, 2009).

Ozumba, A. O. U., and Shakantu, W. M. W. (2008). "Improving The Site Management Process through ICT ${ }^{\mathrm{ee}}$, CIDB 2008 Post Graduate Research Conference, Bloemfontein, South Africa, 7 - 8 March 2008. Wang et al, 2007 
Skills Development Fund, (2011). The Skills Development Fund Manual. Retrieved from http://www.sdfghana.org/new/reports/SDF-Manual.pdf (Accessed on 14th April, 2014)

Tam, C. M. (1999). Use of internet to enhance construction communication. Total information transfer system. Internation jounal of project management, vol 17

World Bank. (1998). The World Development Report 1998/1999

World Bank. (2003). ICT and MDGs: A World Bank Group Perspective. Washington DC. 